\title{
PERANCANGAN SISTEM INFORMASI AKUNTANSI PERMINTAAN DANA UNTUK KEGIATAN PEMBIAYAAN PROYEK PADA PT. TIRSULA INOVASI AMBON
}

\author{
Samuel Ratumurun \\ Universitas Kristen Indonesia Maluku \\ sammy_mahardika@yahoo.com
}

\begin{abstract}
Structuring the accounting information system is one of the factors that determine the performance of companies in managing financial transactions and strategic decision making process. PT. Trisula Inovasi, initially conduct financial transactions in the activities of the project financing is only done by a director and a data entry and assisted by some force field, so the greater the risk of deviations against financial documents and the accounting process, especially on the transaction project financing. This deviation can happen easily, because the absence of the document flow system of structuring financial transactions and integrated them regularly. The purpose of accounting information system design is to produce financial information to support daily operations, management decisions and meet obligations related to accountability and minimizing deviations to be performed by White-collar crime.
\end{abstract}

Keywords: Accounting information system, Financing

\section{PENDAHULUAN}

Perkembangan teknologi informasi dalam era informasi sekarang ini merupaka hal penting yang tidak dapat dipisahkan, dalam melakukan praktek-praktek bisnis. Dunia bisnis dapat berjalan dengan baik dan terus berkembang sangat ditentukan oleh proses pengelolahan, perancangan laporan pertanggunajawaban keuangan dan proses pencatatan akuntansi dari setiap aktivitas yang dilakukan secara tersistem dan tertata dengan baik. Dengan demikian semua elemen pelaku bisnis diharapkan dapat memanfaatkan seluruh potensi sumber daya yang dimilikinya, sehingga dapat lebih berkembang guna bersaing pada persaingan dunia bisnis internasional maupun nasional yang semakin kompleks.

Salah satu hal yang dapat ditempuh oleh perusahaan adalah dengan menciptakan sistem informasi akuntansi yang lebih efisien, praktis dan cepat dalam proses pengelolaan data keuangan maupun non keuangan perusahaan, yang disertai dengan dokumen-dokumen transaksi yang sistimatik dan terarah. Sistem informasi akuntansi yang dapat diandalkan adalah sistem yang mempunyai pengendalian yang memadai sehingga informasi yang dihasilkan oleh sistem tersebut dapat diandalkan untuk digunakan dalam pengambilan keputusan, dalam hal ini pengendalian merupakan elemen yang tidak dapat dipisahkan dari sistem informasi akuntansi yang ada (Romney dan Steinbart, 2005).

Kemajuan teknologi informasi sangat membantu perusahaan dalam mengatur informasi dan proses kegiatan dengan baik. Sehingga dapat mencapai target suatu pencatatan, penyimpanan dan pengolahan data yang lebih efisien, efektif dan praktis. Hal ini akan memudahkan 
perusahaan khususnya pihak manajemen dalam melakukan kegiatan maupun pengambilan keputusan-keputusan yang cermat dalam rangka pencapaian tujuan perusahaan yang diharapkan.

PT. Trisula Inovasi, adalah perusahaan jasa yang bergerak dalam berbagai bidang, antara lain bidang telekomunikasi, pengadaan perangkat keras (hardware) dan perangkat lunak (software), jaringan telekomunikasi, arsitektur, sipil dan kontraktor. Bidang utama pekerjaan yang ditekuni oleh PT. Trisula Inovasi, adalah bidang telekomunikasi dengan menggunakan jaringan satelit.

Dalam menjalankan aktivitasnya, PT. Trisula Inovasi adalah perusahaan jasa pendatang baru dalam kancah perbisnisan Indonesia. Setelah mendapatkan beberapa proyek pada tahun 2012, perusahaan mengalami beberapa kendala dokumentasi dalam proses pembelian barang, pemanfaatan informasi keuangan maupun non keuangan, sistem pembayaran kepada pihak eksternal (pihak ketiga) yang sangat diperlukan oleh pihak manajemen untuk pengambilan keputusan.

Demikian juga dengan proses pembiayaan proyek yang dilakukan yang sangat merugikan. Hal yang menonjol dari beberapa permasalahan di atas adalah tidak terkontrolnya alur sistem keuangan dan akuntansi perusahaan baik dalam proses pembiayaan proyek maupun untuk membiayai kebutuhan rutin perusahaan, dimana sistem pengontrolan perputaran keuangan perusahaan, hanya dikelola oleh dua orang yaitu direktur keuangan dan seorang data entry yang bertugas untuk menginput semua data keuangan ke sistem komputer keuangan yang telah ada dan beberapa tenaga lapangan, namun kadang tidak didukung oleh bukti transaksi yang akurat.

Di sisi lain, tidak adanya sistem pengendalian intern yang baik pada sistem pembiayaan proyek terhadap tahapan permintaan dana maupun aliran dokumen yang diperlukan dan pembiayaan-pembiayaan rutin seperti belanja rutin kantor, padahal akan lebih baik apabila transaksi-transaksi ini dicanangkan melalui sistem akuntansi permintaan dana untuk kegiatan pembiayaan proyek, dengan melibatkan bagianbagian yang relevan.

\section{REVIEW LITERATUR DAN HIPOTESIS}

Dalam dunia bisnis, informasi merupakan komoditas vital bagi semua perusahaan. Bagaimana informasi dihasilkan dan disajikan kepada pihak pengguna, seperti manajer, pelanggan, investor dan kreditur secara baik?. Untuk menjawab pertayaan tersebut maka, perlu adanya suatu mekanisme yang harus di tata sedemikian rupa dalam suatu bentuk sistem, yang terdiri dari komponen-komponen dan prosedur yang baik, sehingga dapat dikatakan sebagai sistem penghasil informasi. Mendahuluinya maka perlu menguraikan tentang konsep dasar sistem dan informasi.

Menurut Nash dan Roberts dalam Jogiyanto (2000) mendefinisikan sistem sebagai suatu kumpulan komponen yang berinteraksi membentuk suatu kesatuan dan keutuhan yang kompleks di dalam tingkat tertentu untuk mengejar tujuan yang umum.

Sistem adalah suatu jaringan kerja dari prosedur-prosedur yang saling berhubungan dikembangkan sesuai dengan suatu skema yang terintegrasi untuk melaksanakan suatu kegiatan utama didalam bisnis" (Jogiyanto, 2000).

Dari berbagai definisi sistem yang disampaikan oleh para pakar sebagaimana diuraikan, dapat disimpulkan menjadi dua kelompok. Pertama, lebih menekankan pada elemen-elemen dalam sistem, yang mana elemen-elemen atau komponen-komponen dari suatu sistem dapat berupa sub sistem. Kedua, lebih menekankan pada prosedur yang merupakan urutan-urutan operasi di dalam sistem.

Dengan demikian sistem dapat didefinisikan dengan pendekatan prosedur dan pendekatan komponen. Dengan pendekatan prosedur, sistem adalah kumpulan dari prosedur-prosedur 
yang mempunyai tujuan tertentu. Contohnya adalah sistem akuntansi. Sistem ini didefenisikan sebagai kumpulan dari prosedur-prosedur penerimaan kas, pengeluaran kas, penjualan, pembelian dan buku besar. Dalam pendekatan komponen, sistem dapat didefenisikan sebagai kumpulan dari komponen yang saling berhubungan satu dengan yang lainnya membentuk satu kesatuan untuk mencapai tujuan tertentu. Contohnya adalah sistem komputer yang didefinisikan sebagai kumpulan dari perangkat keras dan perangkat lunak (Jogiyanto, 2005).

Apakah sebenarnya informasi itu, sehingga sangat penting artinya bagi suatu sistem. Informasi (information) adalah "Data yang telah diletakkan dalam konteks yang lebih berarti dan berguna yang dikomunikasikan kepada penerima untuk digunakan di dalam pembuatan keputusan" demikian dikatakan oleh Burch dan Grudnitski dalam (Jogiyanto, 2000).

Sumber dari informasi adalah data. Data merupakan bentuk jamak dari bentuk tunggal datum atau data-item. Data adalah kenyataan yang menggambarkan suatu kejadian-kejadian dan kesatuan nyata. Kejadian-kejadian (event) adalah suatu yang terjadi pada saat yang tertentu. Di dalam dunia bisnis kejadian-kejadian yang sering terjadi adalah perubahan dari suatu nilai yang disebut dengan transaksi. Itu berarti informasi yang dibutuhkan oleh suatu sistem dalam perusahaan, untuk pengambilan keputusan yang akan dilakukan oleh pihak manajemen, dapat dilakukan secara cermat dengan mempertimbangkan tipe informasi, karakteristik, kualitas dan nilai informasi, sehingga dalam pengambilan keputusan dapat menghasilkan sesuatu yang berguna.

Setelah membahas tentang defenisi sistem dan informasi dari para ahli, maka pada topik ini akan dibahas mengenai defenisi dari sistem informasi. Wilkinson dalam Maulana (1995) mengatakan bahwa Sistem informasi adalah "suatu kerangka kerja sumberdaya (manusia dan komputer) yang dikoordinasikan untuk mengubah masukkan (data) menjadi keluaran (informasi), guna mencapai sasaran-sasaran perusahaan."

\section{Tujuan Sistem Informasi}

Setiap perusahaan harus menyesuaikan sistem informasi dengan kebutuhan para penggunanya. Oleh karenanya, tujuan sistem informasi tertentu dapat saja berbeda antara perusahaan. Akan tetapi, terdapat tiga tujuan dasar yang umum didapati di semua sistem. Adapun tujuan sistem informasi menurut Jogiyanto (2005) adalah.

a. Mendukung fungsi penyediaan (Stewardship) pihak manajemen. Administrasi mengaju pada tanggung jawab pihak manajemen untuk mengelola dengan baik sumber daya perusahaan. Sistem informasi menyediakan menyediakan informasi mengenai penggunaan sumber daya kepada para pengguna eksternal melalui laporan keuangan tradisional serta dari berbagai laporan lain yang diwajibkan. Secara internal, pihak manajemen menerima informasi pelayanan dari berbagai laporan pertanggungjawaban.

b. Mendukung pengambilan keputusan pihak manajemen. Sistem informasi memberikan pihak manajemen informasi yang dibutuhkan untuk melaksanakan tanggung jawab pengambilan keputusan.

c. Mendukung operasional harian perusahaan. Sistem informasi menyediakan informasi bagi para personil operasional untuk mem-bantu mereka melaksanakan pekerjaan hariannya dengan cara yang efisien dan efektif.

\section{Nilai informasi dalam pengambilan keputusan}

Informasi yang dihasilkan oleh SIA yang didesain dengan baik dapat memperbaiki pengembalian keputusan dalam beberapa cara. Pertama, sia dapat mengidentifikasikan berbagai situasi yang membutuhkan tindakan manajemen. Sebagai contoh, sebuah laporan biaya dengan banyak sekali penyimpangan atau perbedaan 
(variance), dapat menstimulasi manajemen untuk menyelidiki dan, jika perlu, mengambil tindakan korektif. Kedua, dengan mengurani ketidakpastian, informasi akuntansi memberikan dasar untuk memilih diantara berbagai alternatif tindakan. Sebagai contoh, informasi akuntasi sering digunakan untuk menetapkan harga dan kebijakan kredit. Ketiga, informasi tentang hasil-hasil keputusan terdahulu memberikan umpan balik (feedback) berharga yang dapat dipakai untuk memperbaiki keputusan di masa mendatang.

Namun demikian, walaupun informasi yang lebih banyak sering kali lebih baik, kondisi ini benar hanya untuk hal tertentu. Terdapat batas jumlah informasi yang dapat diserap dan diproses otak manusia secara efektif. Kelebihan informasi (information everload) terjadi ketika batas tersebut dilewati. Kelebihan informasi itu mahal, karena kualitas pengambilan keputusan menurun sementara biaya untuk menyediakan informasi meningkat. Jadi, kelebihan informasi mengurangi nilai informasi itu sendiri. Oleh karena itu, para perancang sistem informasi harus mempertimbangkan bagaimana kemajuan teknologi informasi dapat membantu para pembuat keputusan secara lebih efektif menyaring dan meringkas informasi, sehingga dapat menghindari kelebihan informasi.

\section{Sistem Informasi Akuntansi}

Organisasi tergantung pada sistem informasi untuk dapat berdaya saing sebab informasi merupakan sumber daya seperti halnya pabrik atau peralatan. Di antara berbagai sistem informasi yang dibutuhkan oleh sebuah organisasi, salah satunya sistem informasi akuntansi.

Akuntansi sebagai suatu sistem informasi, mengindentifikasi, mengumpulkan, memproses dan mengkomunikasikan informasi ekonomi mengenai suatu entitas ke berbagai kelompok orang. Informasi merupakan suatu data yang diorganisasi untuk dapat mendukung ketepatan pengambilan keputusan dan sistem merupakan sekumpulan sumber daya yang saling terkait untuk mencapai suatu tujuan.

Akuntansi adalah "sistem informasi yang mengukur aktivitas bisnis, memproses informasi menjadi laporan keuangan, dan mengkomunikasikan hasilnya kepada pada pengambilan keputusan" (Horngren,2006:4).

Menurut Wilkinson dalam Maulana (1995), akuntansi adalah sebuah sistem informasi. Tepatnya, akuntansi adalah penerapan dari teori umum informasi untuk masalah-masalah operasi ekonomi yang efisien.

Akuntansi juga merupakan bagian besar dari informasi umum yang dinyatakan dalam bentuk kuantitatif. Hubungan yang erat ini juga diakui dengan adanya istilah sistem informasi akuntansi.

Sistem informasi akuntansi didefenisikan sebagai "sistem informasi yang mengubah data transaksi bisnis menjadi informasi keuangan yang berguna bagi pemakainya" (Jogiyanto, 2005:227).

Sistem informasi akuntansi adalah "kumpulan dari sumber-sumber daya semacam orang-orang dan peralatan, dirancang untuk mengubah data ekonomi ke dalam informasi yang berguna" (Bodnar, 2006).

Menurut Wilkinson dalam Mauluna (1995), bahwa Sistem informasi akuntansi adalah "sistem informasi formal yang mengumpulkan, memproses dan menyimpan data serta menyediakan laporan formal yang dibutuhkan."

Dari berbagai defenisi yang dikemukakan di atas, maka dapat disimpulkan bahwa sistem informasi akuntansi adalah sistem informasi formal dari kumpulan sumber daya untuk mengubah data transaksi bisnis menjadi informasi keuangan yang berguna bagi pemakainya.

\section{Tujuan Sistem Informasi Akuntansi}

Melalui informasi yang dihasilkan, sistem informasi akuntansi mempunyai tiga tujuan utama sebagai berikut. 


\section{a. Untuk mendukung operasi sehari-hari}

Sistem informasi akuntansi mempunyai sistem bagian yang disebut dengan TPS (transaction processing system) yang mengolah data transaksi menjadi informasi yang berguna untuk melakukan kegiatan-kegiatan operasi sehari-hari. Contohnya karyawan yang menerima cek pembayaran, supervisor yang memeriksa penjualan tiap harinya, pelanggan yang menerima faktur dan lain sebagainya.

b. Untuk mendukung pengambilan keputusan manajemen

Sistem informasi akuntansi juga dibutuhkan oleh manajemen sebagai dasar pengambilan keputusannya. Manajemen menengah membutuhkan informasi akuntansi untuk melihat penyimpangan-penyimpanagan yang terjadi antara yang dianggarkan dengan nilai realisasi yang dilaporkan oleh sistem informasi akuntansi. Contah lainnya adalah manajemen atas membutuhkan informasi akuntansi untuk perencanaan, misalnya informasi penjualan untuk perencanaan arus kas.

c. Untuk memenuhi kewajiban yang berhubungandenganpertanggungjawaban Manajemen perusahaan perlu melaporkan kegiatannya kepada stakeholder. Stakeholder dapat berupa pemilik, pemegang saham, kreditor, serikat pekerja, pemerintah dan lain sebagainya. Informasi akuntansi yang dibutuhkan oleh stakeholder adalah informasi tentang laporan keuangan yang terdiri dari neraca (posisi keuangan pada tanggal tertentu), laporan laba rugi (laba atau rugi yang diperoleh organisasi selama satu periode tertentu, misalnya selama 1 tahun) dan laporan arus kas (Jogiyanto, 2005).

\section{Perancangan Sistem}

Seperti kita ketahui bahwa siklus hidup pengembangan sistem pada umumnya, yang terdiri dari tahap perencanaan sistem, tahap analisis sistem, tahap desain sistem (perancangan sistem) dan implementasi sistem.
Dalam penulisan ini, akan dibahas mengenai perancangan sistem informasi keuangan, yang berkaitan dengan perancangan alur dokumendokumen penerimaan dan pengeluaran kas kecil sebagai bagian dari sistem informasi keuangan.

Perancangan sistem dapat didefenisikan sebagai penggambaran, perencanaan dan pembuatan sketsa atau pengaturan dari beberapa elemen yang terpisah ke dalam suatu kesatuan yang utuh dan berfungsi (Burch dan Grudnitski dalam Jogiyanto, 2005).

Dari definisi yang dikemukakan oleh para pakar di atas, maka dapat disimpulkan bahwa perancangan sistem adalah suatu kesatuan dari penggambaran, perencanaan dan pembuatan sketsa menyangkut konfigurasi dari komponenkomponen dan prosedur-prosedur suatu sistem untuk memuaskan rancang bangun yang telah ditetapkan pada akhir tahap analisis sistem.

\section{Flowchart}

Flowchart merupakan diagram simbol yang menunjukkan arus data dan tahapan operasi dalam sebuah sistem yang digunakan baik oleh editor maupun oleh personal sistem.

Ada berbagai jenis flowchart secara teori, namun flowchart yang akan digunakan dalam memecahkan permasalahan distribusi dokumen sistem informasi keuangan penerimaan dan pengeluaran kas pada penulisan ini, adalah gabungan antara flowchart analitik, flowchart dokumen dan diagram distribusi formulir. Mengingat pemisahan dan pembagian tugas merupakan elemen pengendalian internal, membutuhkan teknik untuk membagi tugas pengolahan data antar personel dan atau departemen/bagian.

\section{Jenis-Jenis Flowchart}

Adapun jenis-jenis flowchart yang digunakan dalam penelitian ini adalah sebagai berikut.

a. Flowchart Analitik, adalah bagan alir yang ditandai dengan penggunaan simbol yang 
dihubungkan dengan garis. Flowchart analitik mengidentifikasi semua proses signifikan pada sebuah aplikasi, dengan penekanan pada pemrosesan tugas.

b. Flowchart Dokumen, adalah bagan alir yang hanya terdiri dari simbol-simbol dokumen yang digunakan dalam flowchart tersebut. Tetapi, simbol lain pada dasarnya boleh saja digunakan untuk memperjelas suatu flowchart. Tujuan dari flowchart semacam ini adalah untuk mengetahui setiap dokumen yang digunakan dalam setiap sistem aplikasi dan mengidentifikasi titik awal dokumen, distribusi dokumen serta titik akhir setiap dokumen.

Diagram distribusi formulir, adalah diagram alir yang menggambarkan distribusi setiap salinan formulir dalam sebuah organisasi. Dalam diagram ini, penekanannya terletak pada siapa yang akan mendapatkan formulir tertentu, bukan pada bagaimana setiap formulir akan diproses.

\section{METODE PENELITIAN}

Adapun metodologi penelitian yang digunakan dalam penulisan ini adalah metode deskriptif pada PT. Trisula Inovasi Ambon dengan menggunakan model analisis data bagan alir (flowchart), yaitu memecahkan permasalahan-permasalahan pengelolaan sistem informasi akuntansi perusahaan dengan bagan alir dokumen-dokumen secara sistematik dan terarah pada sistem pembiayaan proyek, yang dilakukan oleh PT. Trisula Inovasi.

\section{Jenis Data}

Jenis data yang dikumpulkan berupa data yang terdiri dari data primer dan sekunder. Data primer yang dimaksudkan adalah data yang diperoleh penulis dengan cara melakukan penelitian langsung pada PT. Trisula Inovasi, sedangkan data sekunder adalah data yang diperoleh dari buku-buku bacaan dan litelatur lainnya yang meliputi hasil penelitian tentang sistem informasi akuntansi pembiayaan proyek oleh peneliti sebelumnya yang masih relevan, buku-buku teks mengenai sistem informasi akuntansi yang datanya masih relevan untuk digunakan dan jurnal-jurnal ilmiah.

\section{Teknik Pengumpulan Data}

Teknik pengumpulan data yang digunakan dalam penulisan ini adalah sebagai berikut.

a. Teknis observasi, yaitu dengan melakukan pengamatan langsung terhadap proses kegiatan pembiayaan proyek yang dikerjakan oleh PT. Trisula Inovasi selama Tahun 2014;

b. Teknik wawancara, yaitu dengan melakukan wawancara langsung dengan pimpinan, manajer dan beberapa karyawan untuk mendapatkan informasi;

c. Teknik Kepustakaan, yaitu dengan mencari data pada bagian administrasi atau perpustakaan yang ada pada perusahaan.

\section{Teknik Analisis Data}

Dalam penulisan ini penulis akan menggunakan teknik analisis data yang sesuai yaitu metode teknik analisis data statistik deskriptif. Teknik analisis data statistik deskriptif adalah metode menganalisa data dengan cara mendeskripsikan atau menggambarkan data yang telah terkumpul sebagaimana adanya tanpa bermaksud membuat kesimpulan yang berlaku untuk umum atau generalisasi. Metode ini dipilih karena data yang akan ditampilkan dalam penelitian ini adalah penyajian data melalui tabel, grafik dan gambar-gambar.

\section{HASIL PENELITIAN DAN PEMBAHASAN}

Dalam merancang suatau sistem informasi, sangat perlu untuk ditinjau dari sistem kerja dan pembagian tugas yang tergambar dari rancangan struktur organisasi pada perusahaan dimaksud. Hal ini adalah merupakan sumber utama dalam merancang sebuah sistem informasi yang baik, apalagi berhubungan dengan sistem informasi 
akuntansi perusahan, sebab akan mempengaruhi pihak manejerial dalam pengambilan keputusankeputusan strategis demi kemajuan perusahan tersebut.

Adapun tipe struktur organisasi yang digunakan oleh PT. Trisula Inovasi Ambon adalah tipe struktur organisasi lini dan staf, yang dapat dilihat pada gambar berikut ini.

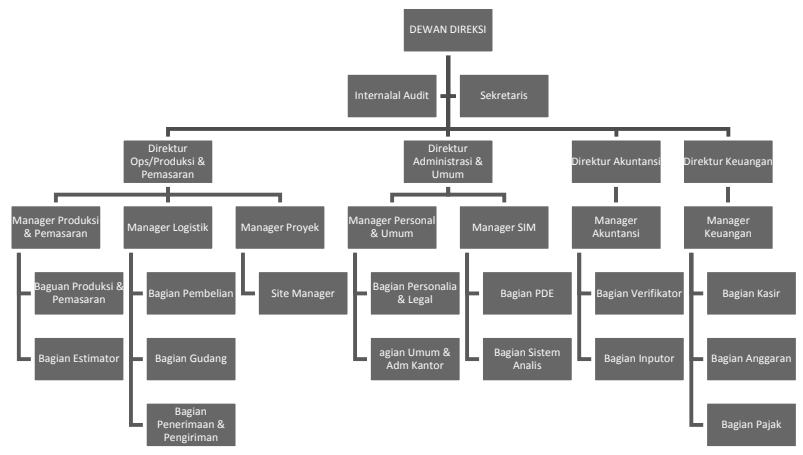

\section{Sistem yang Sedang Berjalan}

Sistem informasi akuntansi PT. Trisula Inovasi pada awal perusahaan ini beraktivitas tidak berjalan sebagaimana mestinya. Sesuai pengamatan penulis sejak mulai penelitian pada bulan juni 2014, sistem informasi keuangan yang diterapkan dengan kondisi karyawan yang hanya beberapa orang, terjadi kekeliruan-kekeliruan pencatatan yang disebabkan karena tidak didukung oleh prosedur dan aliran dokumen yang baik.

Adapun kekeliruan-kekeliruan tersebut, dapat merugikan perusahaan dan juga proses pengambilan keputusan yang strategis oleh pihak manajemen dalam rangka pengembangan perusahaan meliputi, kendala dokumentasi dalam proses pembelian barang, pemanfaatan informasi keuangan maupun non keuangan, sistem pembayaran kepada pihak eksternal (pihak ketiga), proses pembiayaan proyek dari pihak eksternal maupun internal yang sangat merugikan.

Hal yang menonjol dari beberapa kelemahan-kelemahan di atas adalah tidak terkontrolnya alur sistem keuangan perusahaan, baik dalam proses permintaan dana untuk kegiatan pembiayaan proyek maupun untuk membiayai kebutuhan rutin perusahaan Dimana sistem pengontrolan perputaran keuangan perusahaan, hanya dikelolah oleh beberapa orang yaitu direktur keuangan dan seorang data entry yang bertugas untuk menginput semua data keuangan ke sistem komputer database akuntansi yang ada dan beberapa petugas lapangan.

\section{Sistem yang Diusulkan}

Mencermati semua kegiatan keuangan yang terjadi pada PT. Trisula Inovasi dan sistem informasi akuntansi permintaan dana untuk kegiatan pembiayaan proyek yang sedang berjalan, maka sejak diusulkan untuk melakukan perubahan sistem informasi akuntansi permintaan dana untuk pembiayaan proyek seperti yang diuraikan dibawah ini.

Untuk menjelaskan uraian di atas, dengan menggunakan metode flowchart tentang prosedur dan aliran dokumen untuk permintaan dana untuk kegiatan pembiayan proyek pada PT. Trisula Inovasi, adalah sebagai berikut.

\section{Prosedur Dan Aliran Dokumen Untuk Permintaan Dana Untuk Kegiatan Pembiayaan Projek}

Dimulai: ada perusahan lain yang memenangkan tender pengerjaan suatu projek dan mengajukan proposal kepada PT, Trisula Inovasi untuk didanai pekerjaan projeknya tersebut.

1. Perusahaan yang meminta pembiayaan diminta untuk mengajukan proposal, Skedul Anggaran Projek (SAP) dan dokumendokumen yang terkait untuk dievaluasi oleh direksi. Proposal, SAP dan dokumendokumen yang terkait untuk dievaluasi oleh direksi. Proposal, SAP dan dokumendokumen tersebut kemudian diserahkan kepada Direktur Operasional/Produksi untuk memperoleh persetujuan setelah dibahas bersama dengan Direktur Utama. 
2. Jika proposal dari perusahan yang meminta pembiayaan tidak disetujui, maka dikembalikan lagi untuk diperbaiki /hitung ulang oleh perusahan/pelaksana proyek yang meminta pembiayaan atau ditolak sama sekali. proposal yang telah disetujui oleh direksi kemudian diberi approval bahwa perusahan /pelaksana proyek yang bersangkutan telah diterima untuk dibiayai proyeknya.

3. Setiap kali perusahan/pelaksana proyek tersebut membutuhkan dan ia mengajukan permohonan dengan mengisi Formulir Permintaan Dana (FPD) rangkap 3 yang dilampiri dengan Laporan Prestasi Projek (LPP). FPD ke-3 diarsip oleh pelaksana proyek dan lembar ke-1 dan ke-2 diserahkan kepada bagian keuangan, sedangkan LPP dikirimkan kepada direktur produksi untuk diverifikasi.

4. Dengan informasi dari bagian lapangan di proyek direktur operasional/produksi melakukan verifikasi atas LPP yang diterimanya. Jika telah disetujui maka direktur operasional/produksi mengirimkan LPP yang telah diotorisasi kepada bagian keuangan.

5. Bagian keuangan membandingkan LPP yang telah diotorisasi dengan FPD yang telah diterimanya serta membandingkan dengan SAP yang ada dalam arsipnya untuk projek yang bersangkutan; mengeluarkan dana (berupa uang, cek, atau transfer dana) dan membuat $\mathrm{BKK} / \mathrm{BBK}$ rangka 2. LPP, BKK/ BBK lembar ke-2 beserta FPD lembar ke-1

6. Bagian akuntansi berdasarkan data-data yang diterimanya melakukan pengecekan dan verifikasi tentang progress di projek dengan membandingkan LPP dengan SAP yang telah diarsipkanya untuk melakukan kontrol dan pencatatan atas pengakuan pendapatan dan beban sesuai presentase penyelesaian projek setiap bulan maupun untuk mencatat mutasi kasnya sebagai sebuah investasi / kegiatan pembiayaan.

\section{Selesai}

Berikut ini adalah gambaran sistem informasi akuntansi permintaan dana untuk pembiayaan proyek, yang dirancang untuk memudahkan semua karyawan yang terlibat dalam kegiatan pembiayaan proyek tersebut, dengan menggunakan metode diagram bagan alir (Flowcart). Sehingga setiap karyawan tersebut mengerti akan prosedur dan aliran dokumen permintaan dana untuk pembiayaan proyek, dapat dilaksanakan secara tersistem dan tertata secara baik.

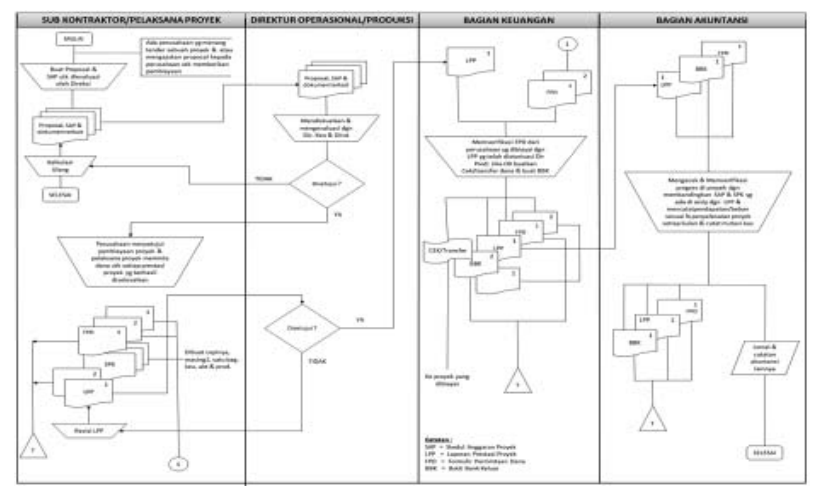

Gambar 1

Prosedur Dan Aliran Dokumen Permintaan Dana Untuk Kegiatan Pembiayan Proyek

\section{KESIMPULAN DAN SARAN}

\section{Kesimpulan}

Kesimpulan yang dapat diambil dari penulisan ini adalah dengan adanya sistem informasi akuntansi yang dirancang oleh penulis dan pihak manajemen perusahaan, maka semua kegiatan keuangan dan alur dokumen keuangan pada PT. Trisula Inovasi, dapat tertata secara teratur dan benar serta kemungkinan terjadinya penyimpangan-penyimpangan atau manipulasi data keuangan dan proses pencatatan akuntansi, dapat ditekan bahkan tidak pernah terjadi lagi. Dengan demikian, sangat memudahkan bagi pihak manajemen atau direksi untuk mengambil keputusan-keputusan strategis demi kemajuan perusahaan. 


\section{Saran}

Beberapa saran yang dapat diberikan kepada perusahaan adalah.

1. Kemajuan usaha perusahaan dalam setahun belakangan ini, mulai berjalan dengan baik sehingga perlu adanya penambahan karyawan pada bidang keuangan dan akuntansi yang khusus menangani tentang semua transaksi hutang dan piutang perusahaan dan bagian unit usaha serta tenaga-tenaga ahli dalam menangani pelaksanaan kegiatan proyek yang dikerjakan oleh perusahaan. Sebab hal ini juga sangat berpengaruhi terhadap perputaran keuangan perusahaan.

2. Perusahaan dapat memberi peluang kepada karyawan yang berkualitas untuk mengikuti program belajar yang dilakukan oleh instansi pemerintah maupun swasta, baik secara formal maupun informal demi pengembangan kualitas sumber daya manusia terhadap bidang ilmu pengetahuan yang berhubungan dengan jenis usaha perusahaan, terutama dalam bidang komputer dan jaringan telekomunikasi satelit serta sistem informasi yang terus berkembang sekarang ini.

\section{DAFTAR PUSTAKA}

Bodnar G.H dan Hopwood W.S, 2006. Sistem Informasi Akuntansi. Edisi Edsi 9, Andi, Yogyakarta;

Christiawan Y.J, 2000. Konsep Pengauditan Dalam Lingkungan Pengolahan Data Akuntansi Terkomputerisasi. Jurnal Akuntansi dan Keuangan, vol.2, No.1 (Mei), Hal. 9 - 20;

Gordon B.D, 1974. Manajement Information System and Conceptual Foundations, Stuctures, and Develompment. International Student edition, McGraw-Hill Kogakusha, Ltd., Tokyo;

Horngren C.T, et all, 2006. Akuntansi, Edisi ke-6, PT. Indeks, Jakarta;
Husein U, 2001. Metode Penelitian Untuk Skripsi dan Tesis Bisnis. PT. Raja-Grafindo Persada, Jakarta;

Hall J.A, 2007. Sistem Informasi Akuntansi. Edisi 4, Salemba Empat, Jakarta;

Jogiyanto, 2000. Sistem Informasi Berbasis Komputer. Edisi 2, BPFE, Yogyakarta; , 2005. Analisis dan Desain Sistem Informasi : Pendekatan Terstruktur Teori dan Praktek Aplikasi Bisnis. Andi, Yogyakarta; , 2005. Sistem Teknologi Informasi Pendekatan Terintegrasi: Konsep dasar, Teknologi, Aplikasi, Pengembangan dan Pengelolaan. Edisi II, Andi, Yogyakarta;

Kendall E.K. dan Kendall J.E, 2006. Analisis dan Perancangan Sistem. Jilid 1 \& 2, Edisi ke 5. PT. Indeks, Jakarta;

Konferensi Nasional Sistem Informasi, 2005. Sistem Informasi. Informatika, Bandung; Krismiaji, 2005. Sistem Informasi Akuntansi. Edisi Kedua, Unit Penerbit dan Percetakan Akademik Manajemen Perusahaan YKPN, Yogyakarta.

Komalasari A, 2001. Rancangan Komputerisasi Sistem Informasi Penjualan Pada PT. $A B C$ Lampung. Jurnal Akuntansi dan Keuangan, Vol. 6, No. 1 ( Januari) Hal. $35-52$

Maulana A, 1995. Sistem Akunting dan Informasi. Jilid 1,2 \& 3, Edisi Ketiga. Binarupa Aksara, Jakarta;

McLeod R, Jr dan Schell G, 2004. Sistem Informasi Manajemen. Edisi Kedelapan. PT. Indeks, Jakarta;

Nugroho A, 2005. Analisis dan Perancangan Sistem Informasi dengan Metodelogi Berorientasi Objek. Edisi Revisi, Informatika, Bandung;

Romney M.B dan Steinbart P.J, 2005. Sistem Informasi Akuntansi. Buku 1 \& 2, Edisi 9, Salemba Empat, Jakarta; 
Sugiyono, 2004. Metode Penelitian Bisnis. CV. Alfabeta, Jakarta;

Tarigan J, 2004. Biometric Security: Alternatif Pengendalian Dalam Sistem Informasi Akuntansi Terkomputerisasi. Jurnal Akuntansi dan Keuangan, vol.6, no.2 (Nopember), Hal. 90 - 105;

Wilopo, 2006. Analisis Faktor-Faktor yang Berpengaruh Terhadap Kecenderungan Kecurangan Akuntansi: Studi pada Perusahaan Publik dan Badan Usaha Milik Negara di Indonesia. Jurnal Riset Akuntansi Indonesia, vol.9, no.3 (September), Hal. : 346-366;
Winarno W.W, 2004. Sistem Informasi Manajemen. UPP AMP YKPN, Yogyakarta;

Yusup A.H, 1999. Dasar-Dasar Akuntansi. Jilid 1, Bagian Penerbit Sekolah Tinggi Ilmu Ekonomi YKPN, Yogyakarta; 